\title{
Brain-derived neurotrophic factor regulates cell motility in human colon cancer
}

\author{
Ssu-Ming Huang, ${ }^{1,2,3}$, Chingju Lin ${ }^{4}$, Hsiao-Yun Lin ${ }^{5}$, Chien-Ming Chiu ${ }^{2}$, Chia-Wei Fang ${ }^{2}$, \\ Kuan-Fu Liao ${ }^{3,6,7}$, Dar-Ren Chen $^{8}$ and Wei-Lan Yeh ${ }^{9}$ \\ ${ }^{1}$ Department of Community Medicine, Preventive Medicine Center, and ${ }^{2}$ Division of Colon and Rectal Surgery, \\ Department of Surgery, Taichung Tzu Chi Hospital, Buddhist Tzu Chi Medical Foundation, Taichung, Taiwan \\ ${ }^{3}$ School of Medicine, Tzu Chi University, Hualien, Taiwan \\ ${ }^{4}$ Department of Physiology, School of Medicine, and ${ }^{5}$ Graduate Institute of Neural and Cognitive Sciences, \\ China Medical University, Taichung, Taiwan \\ ${ }^{6}$ Department of Internal Medicine, Taichung Tzu Chi Hospital, Buddhist Tzu Chi Medical Foundation, \\ Taichung, Taiwan \\ ${ }^{7}$ Department of Chinese Medicine, Graduate Institute of Integrated Medicine, China Medical University, \\ Taichung, Taiwan \\ ${ }^{8}$ Comprehensive Breast Cancer Center, and ${ }^{9}$ Department of Cell and Tissue Engineering, \\ Changhua Christian Hospital, Nanxiao St., Changhua City, Changhua County 500, Taiwan
}

Correspondence should be addressed to W-L Yeh Email ibizayeh0816@hotmail.com

\begin{abstract}
Brain-derived neurotrophic factor (BDNF) is a potent neurotrophic factor that has been shown to affect cancer cell metastasis and migration. In the present study, we investigated the mechanisms of BDNF-induced cell migration in colon cancer cells. The migratory activities of two colon cancer cell lines, HCT116 and SW480, were found to be increased in the presence of human BDNF. Heme oxygenase-1 (HO)-1 is known to be involved in the development and progression of tumors. However, the molecular mechanisms that underlie HO-1 in the regulation of colon cancer cell migration remain unclear. Expression of HO-1 protein and mRNA increased in response to BDNF stimulation. The BDNF-induced increase in cell migration was antagonized by a HO-1 inhibitor and HO-1 siRNA. Furthermore, the expression of vascular endothelial growth factor (VEGF) also increased in response to BDNF stimulation, as did VEGF mRNA expression and transcriptional activity. The increase in BDNF-induced cancer cell migration was antagonized by a VEGF-neutralizing antibody. Moreover, transfection with HO-1 siRNA effectively reduced the increased VEGF expression induced by BDNF. The BDNF-induced cell migration was regulated by the ERK, p38, and Akt signaling pathways. Furthermore, BDNF-increased HO-1 and VEGF promoter transcriptional activity were inhibited by ERK, p38, and AKT pharmacological inhibitors and dominantnegative mutants in colon cancer cells. These results indicate that BDNF increases the migration of colon cancer cells by regulating VEGF/HO-1 activation through the ERK, p38, and PI3K/Akt signaling pathways. The results of this study may provide a relevant contribution to our understanding of the molecular mechanisms by which BDNF promotes colon cancer cell motility.
\end{abstract}

$\begin{aligned} & \text { Key Words } \\ & \text { - BDNF } \\ & \text { - colon cancer } \\ & \text { - migration } \\ & \text { - HO-1 } \\ & \text { - VEGF }\end{aligned}$

Endocrine-Related Cancer (2015) 22, 455-464
(C) 2015 Society for Endocrinology Printed in Great Britain
Published by Bioscientifica Ltd 


\section{Introduction}

Colon cancer is one of the most common gastrointestinal sarcomas and a leading cause of cancer-associated death in developed countries (Siegel et al. 2014). It can be treated by surgery and combination chemotherapy. The etiology of colon cancer remains unclear, but it is believed that environmental factors, genetic factors, and precancerous diseases are associated with the progression of colon cancer (Aarons et al. 2014). Colon cancer can grow into the lumen or adjacent structures, and this is one of the ways in which the disease develops to advanced colon cancer. Approximately $25 \%$ of patients present with metastases at initial diagnosis, and almost 50\% of patients with colon cancer will develop metastases, and these contribute to the high mortality rates (Van Cutsem et al. 2010). The metastases of tumors are associated with a patient's survival, and they account for about $90 \%$ of all colon cancer deaths (Mehlen \& Puisieux 2006). Early diagnosis and treatment may contribute to improvement in the survival rates and prognostic evaluation of colon cancer.

Brain-derived neurotrophic factor (BDNF) is a member of the neurotrophin family that is widely expressed in the mammalian brain (Binder \& Scharfman 2004). BDNF is required for the development and proper functioning of the CNS. It involves in a variety of neural and molecular events and plays an important role in both brain development and synaptic plasticity (Hong et al. 2011). Recently, BDNF has been reported to be associated with tumor progression in several human malignancies, such as neuroblastoma (Czarnecka et al. 2014), lung cancer (Okamura et al. 2012), breast cancer, and colon cancer (Yang et al. 2012, 2013). BDNF and its receptor, TrkB, are commonly upregulated in a variety of human tumors (Guo et al. 2011). Moreover, the overexpression of BDNF and TrkB is related to poor clinical outcome and to reduced survival rates in human breast cancer and bladder cancer (Lai et al. 2010, Patani et al. 2011). The roles played by BDNF/TrkB signaling in breast cancer proliferation and survival have been demonstrated (Ricci et al. 2001). However, the precise biological role of BDNF and its utility as a novel biomarker in colon cancer are still yet to be determined. The objective of the present study was to determine the mechanism that underlies BDNFregulated cell motility in human colon cancer cells.

Vascular endothelial growth factor (VEGF) is a central regulator of angiogenesis in physiological and pathological conditions. VEGF is upregulated in response to hypoxia, activated oncogenes, and a variety of cytokines (Sismanopoulos et al. 2012, Raja et al. 2014). VEGF stimulates normal epithelial cells and differentiated carcinoma cells by inducing epithelial-mesenchymal transition (EMT) (Bates et al. 2003). It has been shown that VEGF signaling synergizes with epidermal growth factor receptor signaling to promote the development of squamous carcinoma (Lichtenberger et al. 2010). It has also been demonstrated that expression of VEGF and VEGFR via the induction of EMT promotes progression to more aggressive tumors in colon carcinoma cells (Bates et al. 2003). Moreover, increased VEGF expression has been found to correlate with an increased incidence of metastasis and decreased patient survival in colon cancer (Takahashi et al. 1995). VEGF-targeted therapy benefits patients with advanced-stage malignancies in colon cancer (Ellis \& Hicklin 2008). During a recent study we determined that VEGF-VEGF receptor interaction promotes colon cancer motility (Huang et al. 2014b). Modulation of VEGF function may contribute to a successful therapeutic treatment of colon cancer and may be applied as a prognostic marker in colon cancer.

In the present study, we investigated the intracellular signaling pathways involved in the BDNF-regulated cell motility in colon cancer cells. Our results indicated that BDNF induced cell migration by upregulating VEGF expression via the induction of heme oxygenase-1 (HO-1). Moreover, BDNF directed the migration of colon cancer cells through the activation of the ERK, p38, and Akt signaling pathways. Therefore, investigation of the molecular mechanism for targeting angiogenesis and migratory pathways in tumors may help in preventing the progression of colon cancer.

\section{Materials and methods}

\section{Materials}

BDNF was purchased from PeproTech (Rocky Hill, NJ, USA). Tin protoporphyrin (SnPP), PD98059, SP600125, and LY294002 were obtained from Sigma-Aldrich. Cobalt protoporphyrin (CoPP), zinc protoporphyrin IX (ZnPP), K252a, and AKT inhibitor (1L-6-hydroxymethyl-chiroinositol 2(R)-2-O-methyl-3-ooctadecylcarbonate) were purchased from Calbiochem (San Diego, CA, USA). VEGF receptor inhibitor $N$-(4-chlorophenyl)-2-((pyridin4-ylmethyl)amino) benzamide was purchased from Merck Co. Fetal bovine serum (FBS), DMEM and OPTI-MEM were purchased from Gibco BRL (Invitrogen Life Technologies). Primary antibody against HO-1 was purchased from StressGen Biotechnologies (Victoria, BC,

Published by Bioscientifica Ltd. 
Canada). Primary antibodies against p-ERK1/2, p-Akt ERK2, p38, JNK, Akt, and $\beta$-actin were purchased from Santa Cruz Biotechnology. Control siRNA and HO-1 siRNA, a pool of five target-specific siRNAs designed to knock down gene expression, were also purchased from Santa Cruz Biotechnology. P-JNK and p-p38 were purchased from Cell Signaling and Neuroscience (Danvers, MA, USA). A luciferase assay kit was purchased from Promega. The DN mutants of ERK (DN-ERK), p38 (DN-p38), AKT (DN-AKT), and VEGF-luciferase plasmids were gifts from Dr W-M Fu (National Taiwan University, Taipei, Taiwan).

\section{Cell cultures}

The human colon carcinoma cell lines HCT-116 and SW480 were obtained from the American Type Culture Collection (Manassas, VA, USA). Short tandem repeat profiles were examined by the Bioresource Collection and Research Center (BCRC, Taiwan) after the present study had concluded to ensure the quality and integrity of these two cell lines. The cell culture protocol was performed as described in our previous publication (Huang et al. 2011). Briefly, cells were grown in plastic cell culture dishes in DMEM, supplemented with $10 \%$ heat-inactivated FBS, $100 \mathrm{U} / \mathrm{ml}$ penicillin, and $100 \mathrm{mg} / \mathrm{ml}$ streptomycin, at $37^{\circ} \mathrm{C}$ in a humidified incubator under an atmosphere of $5 \% \mathrm{CO}_{2}$ and $95 \%$ air. Passages of HCT-116 cells from 46 to 58 and SW480 cells from 19 to 22 were used in the experiments.

\section{Transmigration assay}

An in vitro migration assay was performed using Costar Transwell inserts (Costar, Brooklyn, NY, USA; pore size $8 \mu \mathrm{m}$ ) as described in our previous reports (Chuang et al. 2013, Huang et al. 2014a). Before performing the transmigration assay, cells were pretreated for $30 \mathrm{~min}$ with different concentrations of inhibitors or transfected with various DN mutants for $24 \mathrm{~h}$. On the basis of the results of a cell viability assay, the various concentrations of inhibitors used did not affect colon cancer cell death (data not shown). Approximately $1 \times 10^{4}$ cells in $100 \mu \mathrm{l}$ of serum-free medium were placed in the upper chamber, and $400 \mu \mathrm{l}$ of the same medium containing BDNF were placed in the lower chamber. The plates were incubated for $24 \mathrm{~h}$ at $37^{\circ} \mathrm{C}$ in $5 \% \mathrm{CO}_{2}$, and then the cells were fixed in methanol for $15 \mathrm{~min}$ and stained with $0.05 \%$ crystal violet in PBS for $15 \mathrm{~min}$. Cells on the upper sides of the filters were removed with cotton-tipped swabs, and the filters were washed with PBS. Cells on the undersides of the filters were examined and counted under a microscope.

\section{Transfection}

HCT-116 cells were transiently transfected by $0.8 \mu \mathrm{g}$ dominant-negative mutants of ERK (DN-ERK), p38 (DN-p38), and Akt (DN-AKT), pcDNA3 empty vectors, HO-1 siRNA, or control siRNA with Lipofectamine 2000 (LF2000; Invitrogen) for $24 \mathrm{~h}$. Plasmid DNA and LF2000 were premixed in OPTImedium (Invitrogen Life Technologies) for $20 \mathrm{~min}$ and then applied to the cells. An equal volume of medium containing $20 \%$ FBS was added $6 \mathrm{~h}$ later. After transfection for $24 \mathrm{~h}$, LF2000-containing medium was replaced with fresh, serumfree medium and treated with BDNF for another $24 \mathrm{~h}$. Transfection efficiency was determined by transfection with the plasmid with pEGFP-N1 (Clontech), which utilizes a strong cytomegalovirus (CMV)-immediate early promoter to code for an enhanced green fluorescent protein (GFP) (Supplementary Figure 1, see section on supplementary data given at the end of this article).

\section{Quantitative real time-PCR}

Total RNA was extracted from cells using a Trizol reagent (Invitrogen) and the protocol of the PCR was performed as described in our previous reports (Chuang et al. 2014, Tsai etal. 2015). Briefly, the RT reaction was performed using a RT kit (Promega) and amplified using the following oligonucleotide primers: HO-1 forward: 5'-CACGCCTACACCCGCTACCT-3', reverse: 5'-TCTGTCACCCTGTGCTTGAC-3'; VEGF forward: 5'-CTACCTCCACCATGCCAAGT-3', reverse: 5'-GCAGTAGCTGCGCTGATAGA-3'; GAPDH forward: 5'-AGGGCTGCTTTTAACTCTGGT-3', reverse: 5'-CCCCACTTGATTTTGGAGGGA-3'.

Quantitative real-time PCR using SYBR Green Master Mix was performed by a StepOne Plus System (Applied Biosystems). The threshold was set above the nontemplate control background and within the linear phase of target gene amplification for calculating the cycle number at which the transcript was detected.

\section{Western blot analysis}

The whole-cell lysis extracts were prepared as described in our previous reports (Huang et al. 2013, Tsai et al. 2014). In brief, cells were lysed with a lysis buffer on ice. The supernatants were collected by centrifugation at $13000 \mathrm{~g}$ for $30 \mathrm{~min}$ and stored at $-20^{\circ} \mathrm{C}$. Protein samples were separated by SDS-PAGE and transferred to polyvinylidenedifluoride membranes (Millipore, Bedford, MA, USA). The membranes were blocked with $5 \%$ nonfat milk and probed overnight with primary antibody at $4{ }^{\circ} \mathrm{C}$. After

Published by Bioscientifica Ltd 
undergoing PBS washes, the membranes were incubated with secondary antibody. The blots were visualized by ECL using Kodak X-OMAT LS film (Eastman Kodak). The blots were subsequently stripped by incubation in stripping buffer and probed by a loading control antibody.

\section{Statistical analysis}

Statistical analysis was performed using GraphPad Prism 4.01 Software (GraphPad Software, Inc., San Diego, CA, USA). Values are presented as means \pm s.E.M. Statistical analysis of the difference between two samples was performed using Student's $t$-test.

\section{Results}

\section{BDNF induces the migration activity of human colon cancer cells}

BDNF is significantly elevated in poorly differentiated colon cancer as compared with well-differentiated colon tumors and normal tissue (Yang et al. 2013). To confirm the relationship between the BDNF expression and cell motility in colon cancer, cell migration was examined using the transwell assay. As shown in Fig. 1A, BDNF added to the medium enhanced migration activity in both HCT-116 cells (Fig. 1A) and SW480 cells (Fig. 1B) in a concentration-dependent manner. In order to investigate the role of the BDNF receptor in BDNF-mediated colon cancer cell migration, TrkB inhibitor K252a was used to examine the BDNF-induced colon cancer cell migration. Treatment of HCT-116 cells with K252a markedly inhibited BDNF-induced cell migration in colon cancer cells (Fig. 1C). Furthermore, BDNF also increased migration activity in both HCT-116 cells (Fig. 1D, upper panel) and SW480 cells (Fig. 1D, lower panel).

\section{BDNF-directed colon cancer cell migration involves HO-1 expression}

It has been reported that HO-1 expression is implicated in cell migration and tumor progression (Jozkowicz et al. 2007).
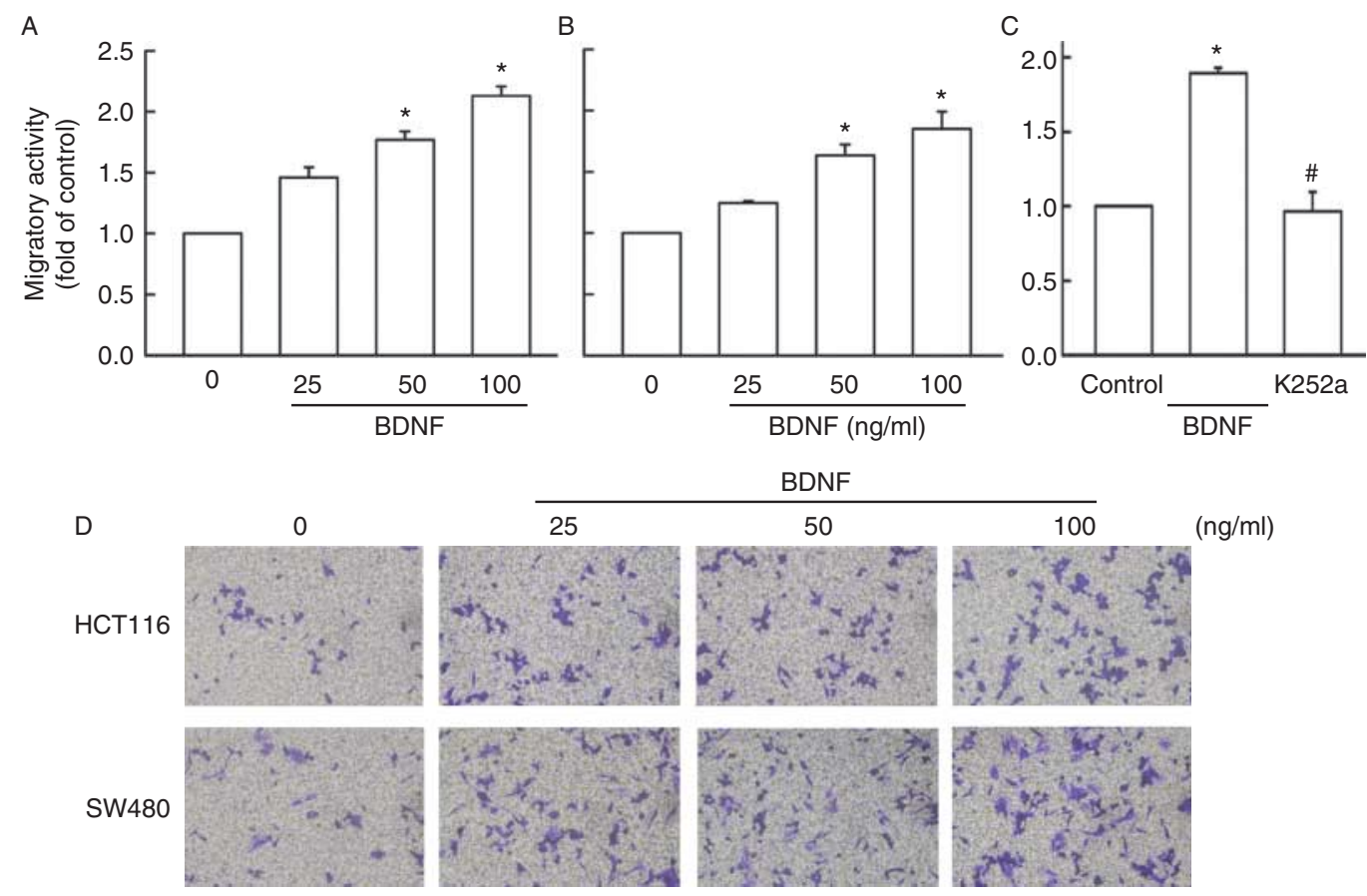

\section{Figure 1}

BDNF induces the migration activity of human colon cancer cells. HCT-116 (A) and SW480 (B) human colon cancer cells were treated with various concentrations of BDNF $(25,50$, or $100 \mathrm{ng} / \mathrm{ml})$. Transmigration activities were measured by transwell assay after BDNF treatment for $24 \mathrm{~h}$. Results are expressed as the means \pm S.E.M. of three independent experiments. The migrated cells were visualized by phase-contrast imaging. (C) HCT-116 cells were incubated with TrkB inhibitor K252a for 30 min and were then
(C) 2015 Society for Endocrinology Printed in Great Britain stimulated with BDNF for $24 \mathrm{~h}$. Transmigratory activity was measured by transwell assay. Results are expressed as the means \pm S.E.M of three independent experiments. ${ }^{*} P<0.05$ as compared with the control group; ${ }^{\#} P<0.05$ as compared with the BDNF treatment group. (D) Cells were seeded on the migration inserts for $24 \mathrm{~h}$ and treated with various concentrations of BDNF ( 25 , 50 , or $100 \mathrm{ng} / \mathrm{ml}$ ) for another $24 \mathrm{~h}$. The migrated cells were determined by transmigration assay and visualized by phase-contrast imaging.

Published by Bioscientifica Ltd 
A

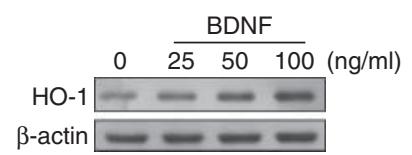

B

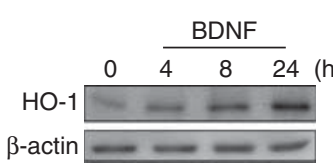

C

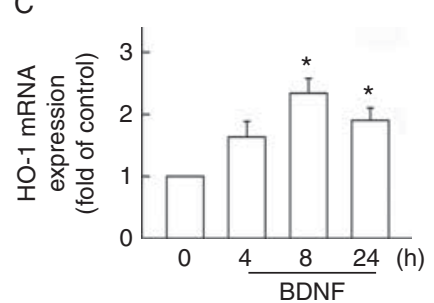

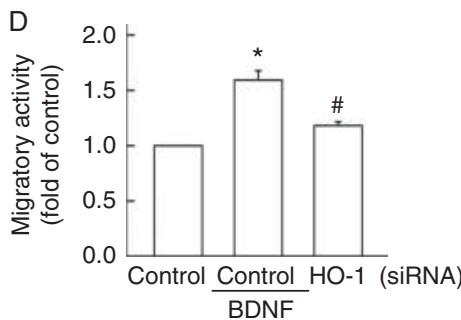

\section{Figure 2}

BDNF increases HO-1 expression in human colon cancer cells. Cells were stimulated with BDNF at various concentrations $(25,50$, or $100 \mathrm{ng} / \mathrm{ml})$ for $24 \mathrm{~h}(\mathrm{~A})$ or with a concentration of $100 \mathrm{ng} / \mathrm{ml}$ for the indicated time periods $(B ; 4,8$, or $24 \mathrm{~h}$ ). After cell lysate extracts were collected, HO-1 protein levels were determined by western blot analysis. (C) Cells were treated with BDNF $(100 \mathrm{ng} / \mathrm{ml})$, and HO-1 mRNA expression was analyzed by RT-PCR. Results are expressed as the means \pm S.E.M of three independent experiments.

The results described in our previous report also indicated that HO-1 participates in glioma cell migration (Lu et al. 2012). As shown in Fig. 2A and B, BDNF increased HO-1 protein expression in concentration- and time-dependent manners. Treatment with BDNF also increased HO-1 mRNA expression, which was determined by quantitative real-time PCR (Fig. 2C). Moreover, the transfection of cells with HO-1 siRNA for $24 \mathrm{~h}$ inhibited BDNF-induced colon cancer cell migration (Fig. 2D). These results indicate that BDNF induces colon cancer cell migration through HO-1 upregulation. Treatment with CoPP, an HO-1 activator, also increased colon cancer cell migration, which further supports the hypothesis that HO-1 is involved in BDNFdirected cell migration in colon cancer cells (Fig. 3A). Furthermore, the HO-1 inhibitors ZnPP and SnPP were used to confirm the BDNF-induced cell migration. Treat-
${ }^{*} P<0.05$ as compared to the control group. (D) Cells were transfected with control or HO-1 siRNA for $24 \mathrm{~h}$ and were then stimulated with BDNF $(100 \mathrm{ng} / \mathrm{ml})$ for another $24 \mathrm{~h}$. Transmigratory activity was measured by transwell assay. Results are expressed as the means \pm S.E.M of three independent experiments. ${ }^{*} P<0.05$ as compared with the control siRNA group; ${ }^{\#} P<0.05$ as compared with the control siRNA BDNF treatment group.

ment of cells with ZnPP or SnPP markedly inhibited BDNFinduced cell migration in HCT116 cells (Fig. 3B and C).

\section{BDNF-directed colon cancer cell migration involves VEGF expression}

Angiogenesis has been found to play an important role in the growth and migratory potential of colon cancer (Bagnasco et al. 2012). In the present study, we further examined whether BDNF regulates expression of the angiogenic factor VEGF in HCT-116 cells. As shown in Fig. 4A and B, BDNF increased VEGF protein expression in concentration- and time-dependent manners. In addition, BDNF increased VEGF mRNA expression in HCT-116 cells (Fig. 4C). We previously demonstrated that transfection with VEGF-luciferase reporter increases
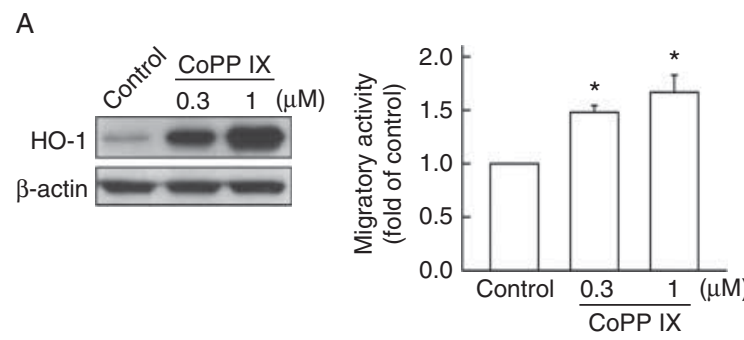

Figure 3

BDNF-directed human colon cancer cell migration involves $\mathrm{HO}-1$ expression. (A) Cells were treated with CoPP $(0.3$ or $1 \mu \mathrm{M})$ for $24 \mathrm{~h}$. HO-1 protein levels were determined by western blot analysis (left panel), and migration activities were examined by transwell assay (right panel). Results are expressed as the means \pm S.E.M. of three independent experiments. ${ }^{*} P<0.05$ as compared with the control group. Cells were incubated with
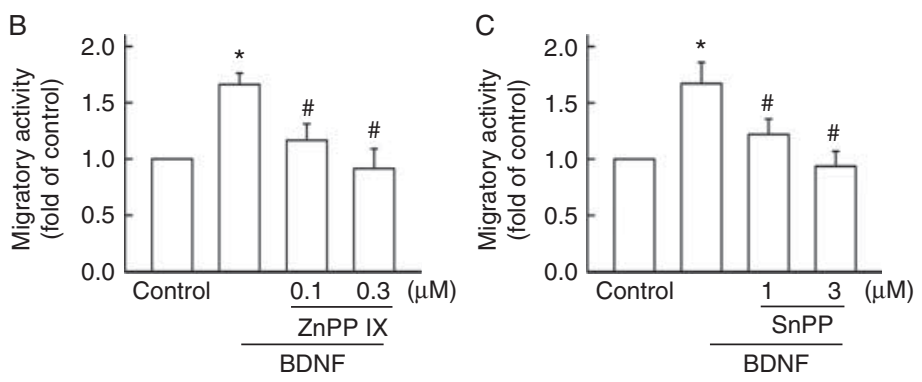

http://erc.endocrinology-journals.org DOI: 10.1530/ERC-15-0007
(C) 2015 Society for Endocrinology Printed in Great Britain
ZnPP (B) or SnPP (C) for 30 min and were then stimulated with BDNF for $24 \mathrm{~h}$. Transmigratory activity was measured by transwell assay. Results are expressed as the means \pm s.E.M. of three independent experiments. ${ }^{*} P<0.05$ as compared with the control group; ${ }^{\#} P<0.05$ as compared with the BDNF treatment group.

Published by Bioscientifica Ltd. 
A

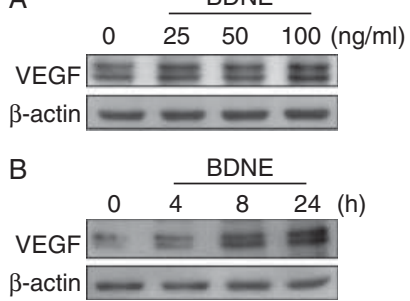

C

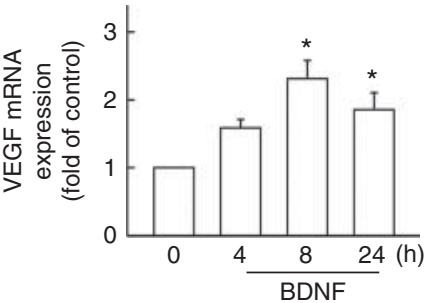

D

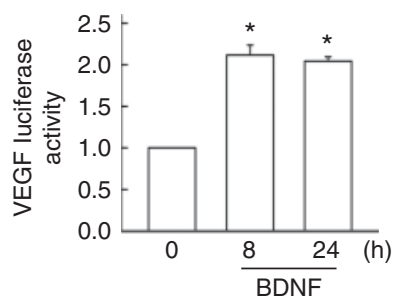

$\mathrm{E}$

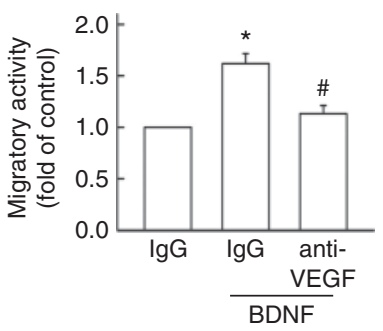

\section{Figure 4}

BDNF increases VEGF expression in human colon cancer. HCT-116 cells were stimulated with BDNF at various concentrations $(25,50$, or $100 \mathrm{ng} / \mathrm{ml})$ for the $24 \mathrm{~h}(\mathrm{~A})$ or with a concentration of $100 \mathrm{ng} / \mathrm{ml}$ for the indicated time periods (B; 4, 8, or $24 \mathrm{~h}$ ). After cell lysate extracts were collected, VEGF protein levels were determined by western blot analysis. (C) Cells were treated with BDNF $(100 \mathrm{ng} / \mathrm{ml})$, and VEGF mRNA expression was analyzed by RT-PCR. Results are expressed as the means \pm s.E.M. of three independent experiments. ${ }^{*} P<0.05$ as compared with the control group. (D) Cells were transfected with the VEGF luciferase expression plasmid for $24 \mathrm{~h}$. The VEGF

VEGF transcriptional activity after stimulation (Huang et al. 2014b). The VEGF-luciferase reporter gene assay was also used to examine the molecular mechanism of BDNFinduced VEGF expression. As shown in Fig. 4D, BDNF also increased VEGF transcriptional activity in HCT-116 cells. Furthermore, the incubation of colon cancer cells with a VEGF-neutralizing antibody markedly inhibited BDNFinduced cancer cell migration (Fig. 4E). Previously, we reported that transfection with $\mathrm{HO}$-1-luciferase reporter increases HO-1 transcriptional activity after stimulation (Chen et al. 2012). In the present study, we further examined the role played by HO-1 and VEGF in BDNF-induced cell migration in colon cancer. Treatment of cells with VEGF receptor inhibitor markedly reduced BDNF-induced HO-1 transcriptional activity (Fig. 5A). However, treatment with ZnPP IX did not affect BDNF-induced VEGF transcriptional activity (Fig. 5B). Furthermore, the transfection of cells with HO-1 siRNA for $24 \mathrm{~h}$ inhibited BDNF-induced HO-1 and VEGF protein expression (Fig. 5C). These results indicate that VEGF regulates BDNF-induced cell migration via the induction of HO-1 expression in colon cancer cells.

\section{ERK, p38, and Akt signaling pathways are involved in BDNF-mediated VEGF/HO-1 upregulation and cell migration in colon cancer cells}

Results of previous studies have indicated that BDNF activates MAP kinase and Akt signaling pathways (Chen et al. 2013, Revest et al. 2014). Therefore, we examined the role of Akt and MAP kinase in HO-1 activation. Our results luciferase activity was assayed after BDNF stimulation for another 8 or $24 \mathrm{~h}$. Results are expressed as the means \pm s.E.M. of three independent experiments. ${ }^{*} P<0.05$ as compared with the control group (E) HCT- 116 cells were incubated with control IgG or VEGF-neutralizing antibody $(5 \mu \mathrm{g})$ and were then stimulated with $100 \mathrm{ng} / \mathrm{ml} \mathrm{BDNF}$. The in vitro migratory activity was measured by transwell assay after BDNF treatment for $24 \mathrm{~h}$. Results are expressed as the means \pm s.E.M. of at least three independent experiments. ${ }^{*} P<0.05$ as compared with the control IgG group; ${ }^{\#} P<0.05$ as compared with the control IgG plus BDNF treatment group.

indicated that the stimulation of cells with BDNF increased the phosphorylation of ERK, p38, and Akt but not JNK (Fig. 6A). Treatment of cells with PD98059, SB203580, or LY294002 effectively reduced the enhancement of BDNF-induced colon cancer migration (Fig. 6B).
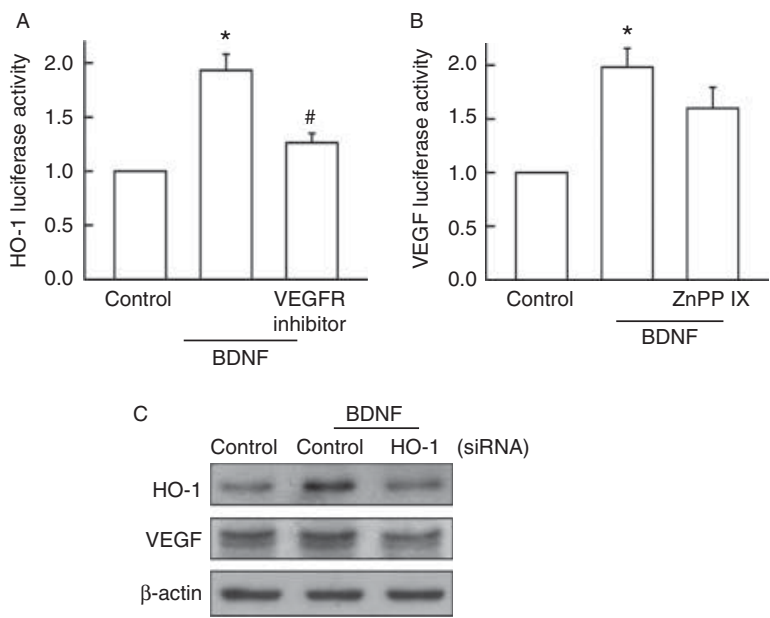

\section{Figure 5}

The involvement of VEGF in BDNF-induced HO-1 expression in human colon cancer cells. (A) Cells were transfected with the HO-1 luciferase expression plasmid for $24 \mathrm{~h}$ and then incubated with VEGFR inhibitor for $30 \mathrm{~min}$.

(B) Cells were transfected with the VEGF luciferase expression plasmid for $24 \mathrm{~h}$ and then incubated with ZnPP for $30 \mathrm{~min}$. The luciferase activity was assayed after BDNF stimulation for another $24 \mathrm{~h}$. Results are expressed as the means \pm S.E.M. of three independent experiments. ${ }^{*} P<0.05$ as compared with the control group; ${ }^{\#} P<0.05$ as compared with the BDNF treatment group. (C) Cells were transfected with control or HO-1 siRNA for $24 \mathrm{~h}$ and were then stimulated with BDNF $(100 \mathrm{ng} / \mathrm{ml})$ for another $24 \mathrm{~h}$. After cell lysate extracts were collected, HO-1 and VEGF protein levels were determined by western blot analysis.

Published by Bioscientifica Ltd. 


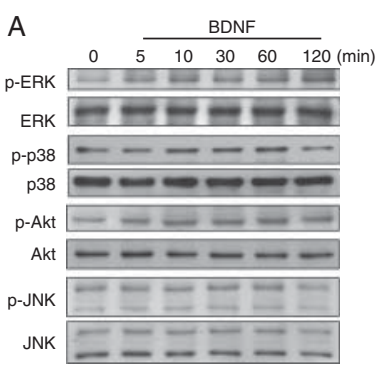

B

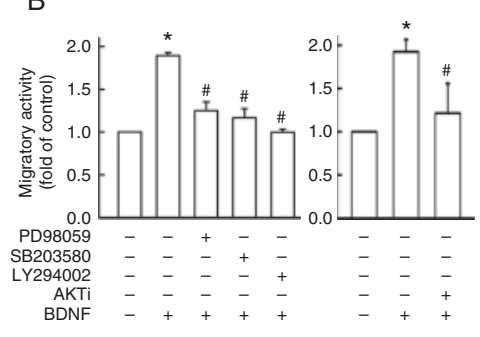

C

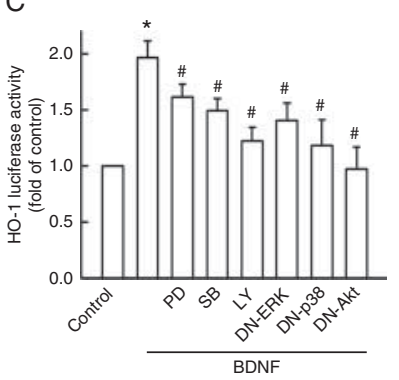

D

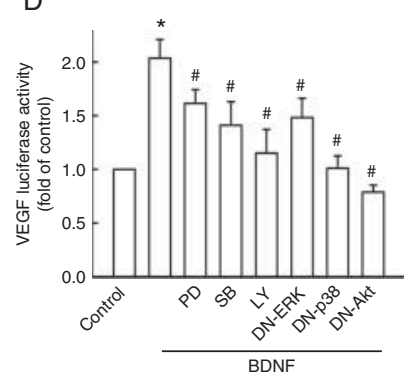

\section{Figure 6}

The involvement of MAP kinase/Akt in BDNF-induced HO-1 expression in human colon cancer cells. (A) Cells were incubated with BDNF for the indicated time periods. The phosphorylation of ERK, p38, Akt, and JNK were determined by western blot analysis. (B) Cells were incubated with PD98059, SB203580, LY294002, or Akt inhibitor (Akti) for $30 \mathrm{~min}$ and were then stimulated with BDNF for $24 \mathrm{~h}$. Transmigratory activity was measured by transwell assay after BDNF treatment for $24 \mathrm{~h}$. Results are expressed as the means \pm s.E.M. of at least three independent experiments. ${ }^{*} P<0.05$ as compared with the control group; ${ }^{\#} P<0.05$ as compared with the BDNF treatment group. (C) Cells were transfected with the luciferase plasmid for $24 \mathrm{~h}$ and then treated with PD98059, SB203580, or LY294002 for $30 \mathrm{~min}$, or they were co-transfected with luciferase plasmid and ERK-DN, p38-DN, or Akt-DN for $24 \mathrm{~h}$. HO-1- (C) and VEGF- (D) luciferase activity were determined. After incubation with BDNF for another $24 \mathrm{~h}, \mathrm{HO}-1$ luciferase activity was measured and the results were normalized to the $\beta$-galactosidase activity. The results are expressed as the means \pm s.E.M. from three independent experiments. ${ }^{*} P<0.05$ as compared with the control group; ${ }^{\#} P<0.05$ as compared with the BDNF treatment group.
In addition, treatment with a specific Akt inhibitor also antagonized the enhancement of BDNF-induced cell motility (Fig. 6B). Next, we further examined whether ERK, p38/MAP kinase, and Akt signaling pathways are involved in BDNF-mediated VEGF/HO-1 upregulation in colon cancer cells. As shown in Fig. 6C and D, treatment with PD98059, SB203580, or LY294002 effectively reduced the BDNF-induced HO-1 and VEGF transcriptional activity in HCT-116 cells. Moreover, transfection with ERK-DN, p38-DN, and Akt-DN reduced the BDNF-induced HO-1 and VEGF transcriptional activity in HCT-116 cells (Fig. 6C and $\mathrm{D})$. These results indicate that BDNF increases VEGF and HO-1 expression through ERK, p38, and Akt activation and promotes colon cancer motility.

\section{Discussion}

Surgery is the primary form of treatment for colon cancer, and it cures approximately 50\% of patients. Recurrence following surgery is a major problem and the leading cause of death from the disease. The 5-year survival rate is approximately $90 \%$ for early colon cancer patients, but that rate decreases to less than $10 \%$ for patients with distant metastases (Coppede et al. 2014). Results of previous studies have indicated that the increased migration and invasion abilities of tumor cells are parallel to EMTs and account for the first step in the invasion of adjacent tissues by tumors and metastases in colon cancer (Hur et al. 2013). Deregulated expression of the proteins that control the cell-extracellular matrix interaction and cell migration have also been found in colon cancer development (Shin et al. 2012, Li et al. 2014).

VEGF seems to be one of the most important mediators of tumoral angiogenesis. Results of a previous study indicated that patients with high-expression variants of VEGF were more likely to develop tumor recurrence (Lurje et al. 2008). Colon cancer patients with VEGF-positive tumors have shown increased tumor recurrence and a resistance to adjuvant chemotherapy (Cascinu et al. 2001). VEGF-directed therapy improves survival for those with metastatic colon cancer (Logan-Collins et al. 2008). Interestingly, VEGF also induces HO-1 expression, which contributes to cytoprotection in acute lung injury (Siner et al. 2007). Results of a previous study also indicated that VEGF mediates the autocrine induction of HO-1 in macrophage (Weis et al. 2009). Importantly, BDNF has been reported to be a potent angiogenic factor that facilitates tumor growth by promoting VEGF expression and angiogenesis in hepatocellular carcinoma (Lam et al. 2011). Recently, we also reported that VEGF-VEGF receptor interaction increases cell motility in human colon cancer (Huang et al. 2014b). The present results support results described in previous reports that VEGF is not only secreted from colon cancer in response to BDNF, but it also causes autocrine-paracrine signaling to further induce HO-1. Therefore, targeting VEGF and its signaling pathway may become a valuable diagnosis predictor for colon cancer.

Heme oxygenase is a rate-limiting enzyme that catalyzes the conversion of heme to carbon monoxide, biliverdin, and iron (Motterlini \& Foresti 2014). HO-1 is a phase II enzyme that is up-regulated in conditions of

Published by Bioscientifica Ltd 
oxidative stress, cellular injury, and disease (Naito et al. 2014). It has been reported that the induction of HO-1 signal pathways has anti-inflammatory and antioxidant effects in macrophage (Chow et al. 2005, Chung et al. 2008, Lin et al. 2014). However, the role of HO-1 in tumorigenesis is still unclear. Upregulation of HO-1 expression has been shown in tumors (Gandini et al. 2014). Moreover, HO-1 expressed in tumor cells has been shown to be associated with shorter survival time for patients (Gandini et al. 2014). On the other hand, results described in some reports have also indicated that HO-1 has anti-tumoral properties and inhibitory effects on tumor progression. HO-1 overexpression reduces cellular proliferation and migration in prostate cancer (Gueron et al. 2009). Moreover, HO-1 serves as a modulator of the angiogenic switch by regulating VEGF in prostate tumorigenesis (Ferrando et al. 2011). Nevertheless, the mechanism that underlies HO-1 and its pathological significance in colon cancer cells remains unclear. In this sense, the need for studying the prognostic significance of HO-1 in colon cancer is urgent. Results of several studies have indicated that neurotrophic factor-enhanced HO-1 expression promotes cancer cell proliferation (Morita et al. 2009). In our previous study and the present report, we investigated the molecular mechanism of HO-1 and its role in cancer cell motility (Lu et al. 2012).

Recently, a clinical observation has been reported that the BDNF mRNA expression level in colon cancer patients was significantly associated with synchronous liver metastasis and peritoneal metastasis (Tanaka et al. 2014). Levels of BDNF in colon cancer patients are significantly elevated in tumors with poor prognosis. Furthermore, colon cancer patients with high levels of BDNF expression had a significantly worse overall survival rate than did those with low levels of BDNF expression (Tanaka et al. 2014). Interestingly, BDNF expression was significantly increased with increasing differentiation of colon cancer and also increased with increasing clinical staging (Yang et al. 2013). It has also been reported that BDNF and TrkB receptor expression was higher in the advanced stages of colon cancer patients (Akil et al. 2011). Importantly, the co-expression of BDNF and the TrkB receptor in colon cancer patients was found to be significantly associated with synchronous liver metastasis and peritoneal metastasis (Tanaka et al. 2014).

Increasing evidence indicates that perineural invasion or the neural cell adhesion molecule might be a prognostic factor for various cancers (Li et al. 2011, 2003). In the present study, we investigated the molecular action of BDNF in the regulation of cell motility in colon cancer.
BDNF has been shown to activate the MAP kinase pathways in the regulation of cell migration and differentiation (Petridis \& El Maarouf 2011). It is known that the MAP kinase and Akt pathways play important roles in colon cancer cell invasion and migration (Tremblay et al. 2006, Huynh et al. 2010, Slattery et al. 2012). The activation of Akt signaling promotes EMT and tumor growth in colon cancer cells (Suman et al. 2014). In the present study, we showed that BDNF induced cell motility and upregulated VEGF expression via the induction of HO-1. Moreover, BDNF-induced cell motility was also modulated by the ERK, p38, and Akt pathways in colon cancer cells. Furthermore, inhibition of the ERK, p38, and Akt pathways effectively antagonized the BDNF-induced HO- 1 and VEGF activity. These results indicate that BDNF activates VEGF expression and HO-1 induction via the ERK, p38, and Akt signaling pathways, which thereby contributes to cell motility in human colon cancer.

Hence, the inhibition of migratory pathways and the molecular mechanism of angiogenesis is an attractive target for colon cancer treatment. There is an urgent need to understand the cellular and molecular factors that promote cancer cell motility. A better understanding of the molecular mechanisms of colon cancer progression may help us find prognostic biomarkers and to develop biological agents for treating colon cancer.

\section{Supplementary data}

This is linked to the online version of the paper at http://dx.doi.org/10.1530/ ERC-15-0007.

\section{Declaration of interest}

The authors declare that there is no conflict of interest that could be perceived as prejudicing the impartiality of the research reported.

\section{Funding}

This work is supported in part by grants from the Ministry of Science and Technology (grant numbers NSC 101-2314-B-303-016-MY3, NSC 102-2320B-039-026-MY3, and NSC 103-2811-B-039-021-), the Taichung Tzu-Chi General Hospital (grant number TTCRD103-18), and the Taiwan Ministry of Health and Welfare Clinical Trial and Research Center of Excellence (grant number MOHW104-TDU-B-212-113002).

\section{References}

Aarons CB, Shanmugan S \& Bleier JI 2014 Management of malignant colon polyps: current status and controversies. World Journal of Gastroenterology 20 16178-16183. (doi:10.3748/wjg.v20.i43.16178)

Akil H, Perraud A, Melin C, Jauberteau MO \& Mathonnet M 2011 Fine-tuning roles of endogenous brain-derived neurotrophic factor.

Published by Bioscientifica Ltd. 
TrkB and sortilin in colorectal cancer cell survival. PLoS ONE 6 e25097. (doi:10.1371/journal.pone.0025097)

Bagnasco L, Piras D, Parodi S, Bauer I, Zoppoli G, Patrone F \& Ballestrero A 2012 Role of angiogenesis inhibitors in colorectal cancer: sensitive and insensitive tumors. Current Cancer Drug Targets 12 303-315. (doi:10.2174/156800912800190929)

Bates RC, Goldsmith JD, Bachelder RE, Brown C, Shibuya M, Oettgen P \& Mercurio AM 2003 Flt-1-dependent survival characterizes the epithelial-mesenchymal transition of colonic organoids. Current Biology 13 1721-1727. (doi:10.1016/j.cub.2003.09.002)

Binder DK \& Scharfman HE 2004 Brain-derived neurotrophic factor. Growth Factors 22 123-131. (doi:10.1080/08977190410001723308)

Cascinu S, Graziano F, Valentini M, Catalano V, Giordani P, Staccioli MP, Rossi C, Baldelli AM, Grianti C, Muretto P et al. 2001 Vascular endothelial growth factor expression, S-phase fraction and thymidylate synthase quantitation in node-positive colon cancer: relationships with tumor recurrence and resistance to adjuvant chemotherapy. Annals of Oncology 12 239-244. (doi:10.1023/A:1008339408300)

Chen JH, Huang SM, Tan TW, Lin HY, Chen PY, Yeh WL, Chou SC, Tsai CF, Wei IH \& Lu DY 2012 Berberine induces heme oxygenase-1 up-regulation through phosphatidylinositol 3-kinase/AKT and NF-E2related factor-2 signaling pathway in astrocytes. International Immunopharmacology 12 94-100. (doi:10.1016/j.intimp.2011.10.019)

Chen A, Xiong LJ, Tong Y \& Mao M 2013 Neuroprotective effect of brainderived neurotrophic factor mediated by autophagy through the PI3K/Akt/mTOR pathway. Molecular Medicine Reports 8 1011-1016. (doi:10.3892/mmr.2013.1628)

Chow JM, Shen SC, Huan SK, Lin HY \& Chen YC 2005 Quercetin, but not rutin and quercitrin, prevention of $\mathrm{H}_{2} \mathrm{O}_{2}$-induced apoptosis via anti-oxidant activity and heme oxygenase 1 gene expression in macrophages. Biochemical Pharmacology 69 1839-1851. (doi:10.1016/ j.bcp.2005.03.017)

Chung HT, Choi BM, Kwon YG \& Kim YM 2008 Interactive relations between nitric oxide (NO) and carbon monoxide (CO): heme oxygenase-1/CO pathway is a key modulator in NO-mediated antiapoptosis and anti-inflammation. Methods in Enzymology $\mathbf{4 4 1}$ 329-338. (doi:10.1016/S0076-6879(08)01218-4)

Chuang JY, Tsai CF, Chang SW, Chiang IP, Huang SM, Lin HY, Yeh WL \& Lu DY 2013 Glial cell line-derived neurotrophic factor induces cell migration in human oral squamous cell carcinoma. Oral Oncology 49 1103-1112. (doi:10.1016/j.oraloncology.2013.08.009)

Chuang JY, Chang PC, Shen YC, Lin C, Tsai CF, Chen JH, Yeh WL, Wu LH, Lin HY, Liu YS et al. 2014 Regulatory effects of fisetin on microglial activation. Molecules 19 8820-8839. (doi:10.3390/molecules19078820)

Coppede F, Lopomo A, Spisni R \& Migliore L 2014 Genetic and epigenetic biomarkers for diagnosis, prognosis and treatment of colorectal cancer. World Journal of Gastroenterology 20 943-956. (doi:10.3748/wjg.v20.i4.943)

Czarnecka M, Trinh E, Lu C, Kuan-Celarier A, Galli S, Hong SH, Tilan JU, Talisman N, Izycka-Swieszewska E, Tsuei J et al. 2014 Neuropeptide Y receptor Y5 as an inducible pro-survival factor in neuroblastoma: implications for tumor chemoresistance. Oncogene [in press]. (doi:10.1038/onc.2014.253)

Ellis LM \& Hicklin DJ 2008 VEGF-targeted therapy: mechanisms of anti-tumour activity. Nature Reviews. Cancer 8 579-591. (doi:10.1038/nrc2403)

Ferrando M, Gueron G, Elguero B, Giudice J, Salles A, Leskow FC, Jares-Erijman EA, Colombo L, Meiss R, Navone N et al. 2011 Heme oxygenase 1 (HO-1) challenges the angiogenic switch in prostate cancer. Angiogenesis 14 467-479. (doi:10.1007/s10456-011-9230-4)

Gandini NA, Fermento ME, Salomon DG, Obiol DJ, Andres NC, Zenklusen JC, Arevalo J, Blasco J, Lopez Romero A, Facchinetti MM et al. 2014 Heme oxygenase-1 expression in human gliomas and its correlation with poor prognosis in patients with astrocytoma. Tumour Biology 35 2803-2815. (doi:10.1007/s13277-013-1373-z)

Gueron G, De Siervi A, Ferrando M, Salierno M, De Luca P, Elguero B, Meiss R, Navone N \& Vazquez ES 2009 Critical role of endogenous heme oxygenase 1 as a tuner of the invasive potential of prostate cancer cells. Molecular Cancer Research 7 1745-1755. (doi:10.1158/1541-7786. MCR-08-0325)

Guo D, Hou X, Zhang H, Sun W, Zhu L, Liang J \& Jiang X 2011 More expressions of BDNF and TrkB in multiple hepatocellular carcinoma and anti-BDNF or K252a induced apoptosis, supressed invasion of HepG2 and HCCLM3 cells. Journal of Experimental \& Clinical Cancer Research 30 97. (doi:10.1186/1756-9966-30-97)

Hong CJ, Liou YJ \& Tsai SJ 2011 Effects of BDNF polymorphisms on brain function and behavior in health and disease. Brain Research Bulletin $\mathbf{8 6}$ 287-297. (doi:10.1016/j.brainresbull.2011.08.019)

Huang SM, Cheung CW, Chang CS, Tang CH, Liu JF, Lin YH, Chen JH, Ko SH, Wong KL \& Lu DY 2011 Phloroglucinol derivative MCPP induces cell apoptosis in human colon cancer. Journal of Cellular Biochemistry 112 643-652. (doi:10.1002/jcb.22966)

Huang BR, Tsai CF, Lin HY, Tseng WP, Huang SS, Wu CR, Lin C, Yeh WL \& Lu DY 2013 Interaction of inflammatory and anti-inflammatory responses in microglia by Staphylococcus aureus-derived lipoteichoic acid. Toxicology and Applied Pharmacology 269 43-50. (doi:10.1016/ j.taap.2013.03.004)

Huang BR, Chang PC, Yeh WL, Lee CH, Tsai CF, Lin C, Lin HY, Liu YS, Wu CY, Ko PY et al. 2014a Anti-neuroinflammatory effects of the calcium channel blocker nicardipine on microglial cells: implications for neuroprotection. PLOS ONE 9 e91167. (doi:10.1371/journal.pone.0091167)

Huang SM, Chen TS, Chiu CM, Chang LK, Liao KF, Tan HM, Yeh WL, Chang GR, Wang MY \& Lu DY $2014 b$ GDNF increases cell motility in human colon cancer through VEGF-VEGFR1 interaction. EndocrineRelated Cancer 21 73-84. (doi:10.1530/ERC-13-0351)

Hur K, Toiyama Y, Takahashi M, Balaguer F, Nagasaka T, Koike J, Hemmi H, Koi M, Boland CR \& Goel A 2013 MicroRNA-200c modulates epithelialto-mesenchymal transition (EMT) in human colorectal cancer metastasis. Gut 62 1315-1326. (doi:10.1136/gutjnl-2011-301846)

Huynh N, Liu KH, Baldwin GS \& He H 2010 P21-activated kinase 1 stimulates colon cancer cell growth and migration/invasion via ERK- and AKT-dependent pathways. Biochimica et Biophysica Acta 1803 1106-1113. (doi:10.1016/j.bbamcr.2010.05.007)

Jozkowicz A, Was H \& Dulak J 2007 Heme oxygenase-1 in tumors: is it a false friend? Antioxidants \& Redox Signaling 9 2099-2117. (doi:10.1089/ ars.2007.1659)

Lai PC, Chiu TH \& Huang YT 2010 Overexpression of BDNF and TrkB in human bladder cancer specimens. Oncology Reports 24 1265-1270. (doi:10.3892/or_00000981)

Lam CT, Yang ZF, Lau CK, Tam KH, Fan ST \& Poon RT 2011 Brain-derived neurotrophic factor promotes tumorigenesis via induction of neovascularization: implication in hepatocellular carcinoma. Clinical Cancer Research 17 3123-3133. (doi:10.1158/1078-0432.CCR-10-2802)

Li R, Wheeler T, Dai H \& Ayala G 2003 Neural cell adhesion molecule is upregulated in nerves with prostate cancer invasion. Human Pathology 34 457-461. (doi:10.1016/S0046-8177(03)00084-4)

Li D, Peng X, Yan D, Tang H, Huang F, Yang Y \& Peng Z 2011 Msi-1 is a predictor of survival and a novel therapeutic target in colon cancer. Annals of Surgical Oncology 18 2074-2083. (doi:10.1245/s10434-011-1567-9)

Li Y, Zhao Z, Xu C, Zhou Z, Zhu Z \& You T 2014 HMGA2 induces transcription factor Slug expression to promote epithelial-tomesenchymal transition and contributes to colon cancer progression. Cancer Letters 355 130-140. (doi:10.1016/j.canlet.2014.09.007)

Lichtenberger BM, Tan PK, Niederleithner H, Ferrara N, Petzelbauer P \& Sibilia M 2010 Autocrine VEGF signaling synergizes with EGFR in tumor cells to promote epithelial cancer development. Cell $\mathbf{1 4 0}$ 268-279. (doi:10.1016/j.cell.2009.12.046)

Lin HY, Huang BR, Yeh WL, Lee CH, Huang SS, Lai CH, Lin H \& Lu DY 2014 Antineuroinflammatory effects of lycopene via activation of adenosine monophosphate-activated protein kinase- $\alpha 1 /$ heme oxygenase- 1 pathways. Neurobiology of Aging 35 191-202. (doi:10.1016/ j.neurobiolaging.2013.06.020) 
Logan-Collins JM, Lowy AM, Robinson-Smith TM, Kumar S, Sussman JJ, James LE \& Ahmad SA 2008 VEGF expression predicts survival in patients with peritoneal surface metastases from mucinous adenocarcinoma of the appendix and colon. Annals of Surgical Oncology 15 738-744. (doi:10.1245/s10434-007-9699-7)

Lu DY, Yeh WL, Huang SM, Tang CH, Lin HY \& Chou SJ 2012 Osteopontin increases heme oxygenase-1 expression and subsequently induces cell migration and invasion in glioma cells. Neuro-Oncology 14 1367-1378. (doi:10.1093/neuonc/nos262)

Lurje G, Zhang W, Schultheis AM, Yang D, Groshen S, Hendifar AE, Husain H, Gordon MA, Nagashima F, Chang HM et al. 2008 Polymorphisms in $V E G F$ and $I L-8$ predict tumor recurrence in stage III colon cancer. Annals of Oncology 19 1734-1741. (doi:10.1093/annonc/mdn368)

Mehlen P \& Puisieux A 2006 Metastasis: a question of life or death. Nature Reviews. Cancer 6 449-458. (doi:10.1038/nrc1886)

Morita K, Lee MS \& Her S 2009 Possible relation of hemin-induced HO-1 expression to the upregulation of VEGF and BDNF mRNA levels in rat C6 glioma cells. Journal of Molecular Neuroscience 38 31-40. (doi:10.1007/s12031-008-9156-5)

Motterlini R \& Foresti R 2014 Heme oxygenase-1 as a target for drug discovery. Antioxidants \& Redox Signaling 20 1810-1826. (doi:10.1089/ ars.2013.5658)

Naito Y, Takagi T \& Higashimura Y 2014 Heme oxygenase-1 and anti-inflammatory M2 macrophages. Archives of Biochemistry and Biophysics 564C 83-88. (doi:10.1016/j.abb.2014.09.005)

Okamura K, Harada T, Wang S, Ijichi K, Furuyama K, Koga T, Okamoto T, Takayama K, Yano T \& Nakanishi Y 2012 Expression of TrkB and BDNF is associated with poor prognosis in non-small cell lung cancer. Lung Cancer 78 100-106. (doi:10.1016/j.lungcan.2012.07.011)

Patani N, Jiang WG \& Mokbel K 2011 Brain-derived neurotrophic factor expression predicts adverse pathological and clinical outcomes in human breast cancer. Cancer Cell International 11 23. (doi:10.1186/ 1475-2867-11-23)

Petridis AK \& El Maarouf A 2011 Brain-derived neurotrophic factor levels influence the balance of migration and differentiation of subventricular zone cells, but not guidance to the olfactory bulb. Journal of Clinical Neuroscience 18 265-270. (doi:10.1016/j.jocn.2010.06.021)

Raja R, Kale S, Thorat D, Soundararajan G, Lohite K, Mane A, Karnik S \& Kundu GC 2014 Hypoxia-driven osteopontin contributes to breast tumor growth through modulation of HIF1 $\alpha$-mediated VEGF-dependent angiogenesis. Oncogene 33 2053-2064. (doi:10.1038/onc.2013.171)

Revest JM, Le Roux A, Roullot-Lacarriere V, Kaouane N, Vallee M, Kasanetz F, Rouge-Pont F, Tronche F, Desmedt A \& Piazza PV 2014 BDNF-TrkB signaling through Erk $1 / 2^{\mathrm{MAPK}}$ phosphorylation mediates the enhancement of fear memory induced by glucocorticoids. Molecular Psychiatry 19 1001-1009. (doi:10.1038/mp.2013.134)

Ricci A, Greco S, Mariotta S, Felici L, Bronzetti E, Cavazzana A, Cardillo G, Amenta F, Bisetti A \& Barbolini G 2001 Neurotrophins and neurotrophin receptors in human lung cancer. American Journal of Respiratory Cell and Molecular Biology 25 439-446. (doi:10.1165/ajrcmb.25.4.4470)

Shin S, Wolgamott L \& Yoon SO 2012 Integrin trafficking and tumor progression. International Journal of Cell Biology 2012516789. (doi:10.1155/2012/516789)

Siegel R, Desantis C \& Jemal A 2014 Colorectal cancer statistics, 2014. CA: A Cancer Journal for Clinicians 64 104-117. (doi:10.3322/caac.21220)
Siner JM, Jiang G, Cohen ZI, Shan P, Zhang X, Lee CG, Elias JA \& Lee PJ 2007 VEGF-induced heme oxygenase-1 confers cytoprotection from lethal hyperoxia in vivo. FASEB Journal 21 1422-1432. (doi:10.1096/fj. 06-6661 com)

Sismanopoulos N, Delivanis DA, Alysandratos KD, Angelidou A, Vasiadi M, Therianou A \& Theoharides TC 2012 IL-9 induces VEGF secretion from human mast cells and IL-9/IL-9 receptor genes are overexpressed in atopic dermatitis. PLoS ONE 7 e33271. (doi:10.1371/journal.pone. 0033271)

Slattery ML, Lundgreen A \& Wolff RK 2012 MAP kinase genes and colon and rectal cancer. Carcinogenesis 33 2398-2408. (doi:10.1093/carcin/ bgs305)

Suman S, Kurisetty V, Das TP, Vadodkar A, Ramos G, Lakshmanaswamy R \& Damodaran C 2014 Activation of AKT signaling promotes epithelialmesenchymal transition and tumor growth in colorectal cancer cells. Molecular Carcinogenesis 53 (Suppl 1) E151-E160. (doi:10.1002/mc. 22076)

Takahashi Y, Kitadai Y, Bucana CD, Cleary KR \& Ellis LM 1995 Expression of vascular endothelial growth factor and its receptor, KDR, correlates with vascularity, metastasis, and proliferation of human colon cancer. Cancer Research 55 3964-3968.

Tanaka K, Okugawa Y, Toiyama Y, Inoue Y, Saigusa S, Kawamura M, Araki T, Uchida K, Mohri Y \& Kusunoki M 2014 Brain-derived neurotrophic factor (BDNF)-induced tropomyosin-related kinase B (Trk B) signaling is a potential therapeutic target for peritoneal carcinomatosis arising from colorectal cancer. PLoS ONE 9 e96410. (doi:10.1371/journal.pone. 0096410)

Tremblay PL, Auger FA \& Huot J 2006 Regulation of transendothelial migration of colon cancer cells by E-selectin-mediated activation of p38 and ERK MAP kinases. Oncogene 25 6563-6573. (doi:10.1038/sj.onc. 1209664)

Tsai CF, Yeh WL, Chen JH, Lin C, Huang SS \& Lu DY 2014 Osthole suppresses the migratory ability of human glioblastoma multiforme cells via inhibition of focal adhesion kinase-mediated matrix metalloproteinase-13 expression. International Journal of Molecular Sciences $\mathbf{1 5}$ 3889-3903. (doi:10.3390/ijms15033889)

Tsai CF, Kuo YH, Yeh WL, Wu CY, Lin HY, Lai SW, Liu YS, Wu LH, Lu JK \& Lu DY 2015 Regulatory effects of caffeic acid phenethyl ester on neuroinflammation in microglial cells. International Journal of Molecular Sciences 16 5572-5589. (doi:10.3390/ijms16035572)

Van Cutsem E, Nordlinger B, Cervantes A \& Group EGW 2010 Advanced colorectal cancer: ESMO Clinical Practice Guidelines for treatment. Annals of Oncology 21 (Suppl 5) v93-v97. (doi:10.1093/annonc/ mdq222)

Weis N, Weigert A, von Knethen A \& Brune B 2009 Heme oxygenase-1 contributes to an alternative macrophage activation profile induced by apoptotic cell supernatants. Molecular Biology of the Cell 20 1280-1288. (doi:10.1091/mbc.E08-10-1005)

Yang X, Martin TA \& Jiang WG 2012 Biological influence of brain-derived neurotrophic factor on breast cancer cells. International Journal of Oncology 41 1541-1546. (doi:10.3892/ijo.2012.1581)

Yang X, Martin TA \& Jiang WG 2013 Biological influence of brain-derived neurotrophic factor (BDNF) on colon cancer cells. Experimental and Therapeutic Medicine 6 1475-1481. (doi:10.3892/etm.2013.1330)

Received in final form 2 April 2015

Accepted 14 April 2015

Made available online as an Accepted Preprint

15 April 2015 http://erc.endocrinology-journals.org DOI: 10.1530/ERC-15-0007
(C) 2015 Society for Endocrinology Printed in Great Britain
Published by Bioscientifica Ltd. 